\title{
Push-out bond strength of different tricalcium silicate-based filling materials to root dentin
}

\section{Jorge Henrique STEFANELI MARQUES(a) \\ Yara Teresinha Corrêa SILVA-SOUSA(a) \\ Fuad Jacob Abi RACHED-JÚNIOR(a) Luciana Martins Domingues de MACEDO $^{(a)}$ \\ Jardel Francisco MAZZI-CHAVES(b) \\ Josette CAMILLERI(c) \\ Manoel Damião SOUSA-NETO(b)}

(a) Universidade de Ribeirão Preto - Unaerp, School of Dentistry, Ribeirão Preto, SP, Brazil.

(b) Universidade de São Paulo - USP, School of Dentistry of Ribeirão Preto, Department of Restorative Dentistry, Ribeirão Preto, SP, Brazil.

(c) University of Birmingham, School of Dentistry, Edgbaston, Birmingham, UK.

Declaration of Interest: The authors certify that they have no commercial or associative interest that represents a conflict of interest in connection with the manuscript.

\section{Corresponding Author:}

Fuad Jacob Abi Rached Junior

E-mail: rached-junior@hotmail.com

https://doi.org/10.1590/1807-3107bor-2018.vol32.0018

Submitted: October 04, 2017

Accepted for publication: January 29, 2018

Last revision: February 02, 2018

\begin{abstract}
The aim of this study was to evaluate the bond strength of different triccalcium silicate cements to retrograde cavity using a push out test. Thirty maxillary central incisors were shaped using \#80 hand files and sectioned transversally. Root slices were obtained from the apical 4 $\mathrm{mm}$ after eliminating the apical extremity. The specimens were embedded in acrylic resin and positioned at $45^{\circ}$ to the horizontal plane for preparation of root-end cavities with a diamond ultrasonic retrotip. The samples were divided into three groups according to the root-end filling material $(n=10)$ : MTA Angelus, ProRoot MTA and Biodentine. A gutta-percha cone (\#80) was tugged-back at the limit between the canal and the root-end cavity. The root-end cavity was filled and the gutta-percha cone was removed after complete setting of the materials. The specimens were placed in an Instron machine with the root-end filling turned downwards. The push-out shaft was inserted in the space previously occupied by the gutta-percha cone and push out testing was performed at a crosshead speed of $1.0 \mathrm{~mm} / \mathrm{min}$. There was no statistically significant difference in resistance to push out by the materials tested $(p>0.01)$. MTA Angelus and ProRoot MTA showed predominantly mixed failure while Biodentine exhibited mixed and cohesive failures. The tricalcium silicate-based root-end filling materials showed similar bond strength retrograde cavity.
\end{abstract}

Keywords: Endodontics; Biocompatible Materials; Dental Materials.

\section{Introduction}

Endodontic surgery is indicated in cases of periradicular infection remaining after endodontic retreatment. ${ }^{1}$ The choice of the root-end filling material affects the treatment outcome. ${ }^{2}$ Thus, an ideal root-end filling material must exhibit the following properties: biocompatibility with periapical tissues, ${ }^{3,4}$ low cytotoxicity ${ }^{5}$ and solubility, ${ }^{6}$ appropriate marginal sealing, ${ }^{7}$ bond strength to dentin,${ }^{8}$ and bioactivity. ${ }^{9}$

Mineral trioxide aggregate (MTA) has calcium silicate (66.1\%), calcium silicate $(8.4 \%)$, calcium aluminate $(2.0 \%)$, bismuth oxide $(14 \%)$, calcium oxide $(8.0 \%)$, silicon oxide ) and aluminum oxide $(1.0 \%)$, which was the first material to be formulated specifically as a root-end filling material, interacted with periapical fluids and induced formation of hydroxyapatite, ${ }^{10}$ leading to the filling of dentin tubules, closure of gaps at the dentin/material interface, and apical sealing. ${ }^{11}$ 
The interaction of MTA with tissue fluids is a result of the reaction of calcium hydroxide, a by-product of MTA hydration, with the phosphates found in the tissue fluids. Thus, all tricalcium silicate-based materials potentially exhibit this interaction. Biodentine is also based on tricalcium silicate; thus, its interaction with phosphate-containing tissue fluid has been proposed. ${ }^{12,13}$

ProRoot MTA, the first MTA to become clinically available and to undergo most research, is composed of tricalcium silicate $(53.1 \%)$, dicalcium silicate $(22.5 \%)$, bismuth oxide (21.6\%), and small quantities of tricalcium aluminate and calcium sulfate. ${ }^{13,14}$ This material is indicated for surgical and non-surgical procedures. The cement consists of thin hydrophilic particles that set in a humid environment after $3-4 \mathrm{~h}$ at a of $\mathrm{pH} 12.5 .^{3}$

Mineral trioxide aggregate (MTA Angelus) is composed of tricalcium (66.1\%) and dicalcium (8.4\%) silicate, tricalcium aluminate $(2.0 \%)$, calcium sulfate (5.0\%), and bismuth oxide $(14 \%),{ }^{1}$, being indicated for direct pulp capping, in perforations, apexations and as a retrofilling material. ${ }^{13,14}$

Biodentine was commercially released in 2009 as a dentin substitute. ${ }^{12}$ Its powder is composed of tricalcium silicate $(80,1 \%)$, calcium carbonate $(14,9 \%)$, and zirconium oxide as radiopacifiers (5\%), whereas the liquid contains calcium chloride and a water-soluble polymer for providing appropriateflow at a low powder/ liquid ratio ${ }^{14}$. This cement exhibits physicochemical ${ }^{15}$ and biological properties ${ }^{16}$ similar to Portland cement and has the consistency of phosphate-based cement. ${ }^{16}$

Bioactivity or the interaction of root-end filling materials to root dentin depends on their chemical composition and presence of phosphate in the biological tissue fluids ${ }^{9}$. Thus, the measurement of bond strength of tricalcium silicate and phosphate-based cements is important to enable quantification of the dentin/material interaction. Usually, the bond strength of root-end filling materials is evaluated using push-out test on slices of the middle third of the $\operatorname{root}^{8,17}$ and artificial perforations $s^{18}$ and is similar to the method suggested for the evaluation of root canal sealers. The dentin in the middle third of the root has a higher density of dentin tubules with greater diameter than that in the apical third. ${ }^{19}$ These characteristics may influence the bond strength of root-end filling materials. Thus, the aim of this study was to evaluate the bond strength of the root-end filling materials based on tricalcium silicate, including MTA Angelus, ProRoot MTA, and Biodentine, using a specific push out test for retrofilling cements. The following hypothesis was tested: the proportion of tricalcium silicate in each cement does not interfere on the bond strength in the retrograde cavity.

\section{Methodology}

This study was approved by the Human Ethics Committee of the Institutional Review Board (Committee process $n^{\circ}$. 15661713.2.0000.5498).

Thirty maxillary central incisors were examined macro and microscopically under stereoscopic at $25 \mathrm{x}$ and radiographed in a bucco-palatal direction. The criteria for inclusion were complete formation, absence of calcifications, pulp nodules and internal reabsorption. The criteria for exclusion were: root fracture, previous endodontic treatment and the presence of dentinal defects in the external morphology of the roots. The teeth were sectioned horizontally close to the cementoenamel junction using a diamond disc under constant water cooling to obtain $16-\mathrm{mm}$ long roots. The root canal length was determined with a size 15 K-file (Maillefer, Ballaigues, Switzerland), which was introduced passively into the canal until its tip was visible at the apical foramen. Working length was calculated by subtracting $1 \mathrm{~mm}$ from the total canal length. The canals were prepared initialy from K-file \#80 (Maillefer) by inserting in a handpiece with alternating motion (NSK, Kanuma, Tochigi, Japan) and then the preparation was complemented with the drills Gates-Glidden drills \#3, \#4, and \#5 (Maillefer) and the K-file \#90. The canals were irrigated with $2 \mathrm{~mL}$ of $1 \% \mathrm{NaOCl}$ between the use of each file and drill, and final irrigation was performed with $2 \mathrm{~mL}$ of $17 \%$ EDTA for $5 \mathrm{~min}$, followed by irrigation with $5 \mathrm{~mL}$ of distilled water. The canals were dried with absorbent paper points.

After biomechanical preparation, the roots were sectioned transversally at the following two points: $2 \mathrm{~mm}$ short of the apical foramen (the level of apicectomy) and $4 \mathrm{~mm}$ coronally to this point. ${ }^{20}$ This secction of the roots were embedded individually in aluminum rings $(16 \mathrm{~mm}$ in diameter and $4 \mathrm{~mm}$ in 
height) containing clear self-curing acrylic resin ${ }^{20}$. The specimens were positioned in a device at $45^{\circ}$ to the horizontal plane during preparation and restoration of the root-end cavities stainless steel. The root-end cavities were prepared using a diamond ultrasonic retrotip (ST12D-Mani; Mani, Inc. Takanezawa, Tochigi-Ken, Japan) coupled to a ultrasound unit (U.S. Profi II-AS; Dabi Atlante, Ribeirão Preto, Brazil) set at power $3(24 \mathrm{~W})$ and $24-28 \mathrm{KHz}$ under constant cooling with distilled and deionized water. Root-end cavities with standardized dimensions $(1.5 \mathrm{~mm}$ diameter and $2 \mathrm{~mm}$ deep) were prepared by making intermittent forward-backward movements with the retrotip for $17 \mathrm{~s}$, with penetration limited to $2 / 3$ of its active part ${ }^{20}$. The root-end cavities were rinsed with $2 \mathrm{~mL}$ of saline using a NaviTip (Ultradent Products Inc., South Jordan, USA) and dried with absorbent paper cones ${ }^{20}$.

The specimens were divided into three groups ( $n=10)$ based on the root-end filling material used for restoration of the root-end cavities: MTA Angelus (Angelus, Londrina, Brazil), ProRoot MTA (Dentsply Tulsa Dental Specialties, Konstanz, Germany), and Biodentine (Septodont Ltda., Saint Maur-des-Fosses, Paris, France). Filling of the root-end cavities and push-out tests were performed according to the protocol suggested by Marques et al. ${ }^{20}$ The materials were manipulated according to the manufacturers' instructions. In each specimen, a master gutta-percha cone (\#80) was tug-backed at the limit between the rootend cavity and the canal (Figure 1A), and the root-end filling material was inserted into the root-end cavity with an amalgam carrier, condensed with appropriatesize condensers, and burnished. Following a time period three times longer than the setting time of each cement, the gutta-percha cones were removed from the canal. The specimen was then fixed in an Instron 4444 universal testing machine (Instron Corp., Canton, USA) with the root-end filling facing downwards and aligning to the shaft (Figure 1B). The push-out cylindrical tip with a $1.0 \mathrm{~mm}$ diameter was inserted in the space previously occupied by the guttapercha cone and push out testing was performed at a crosshead speed of $1.0 \mathrm{~mm} / \mathrm{min} .{ }^{17}$ Data were obtained in MPa and statistically analyzed by one-way analysis of variance $(a=0.05)$.

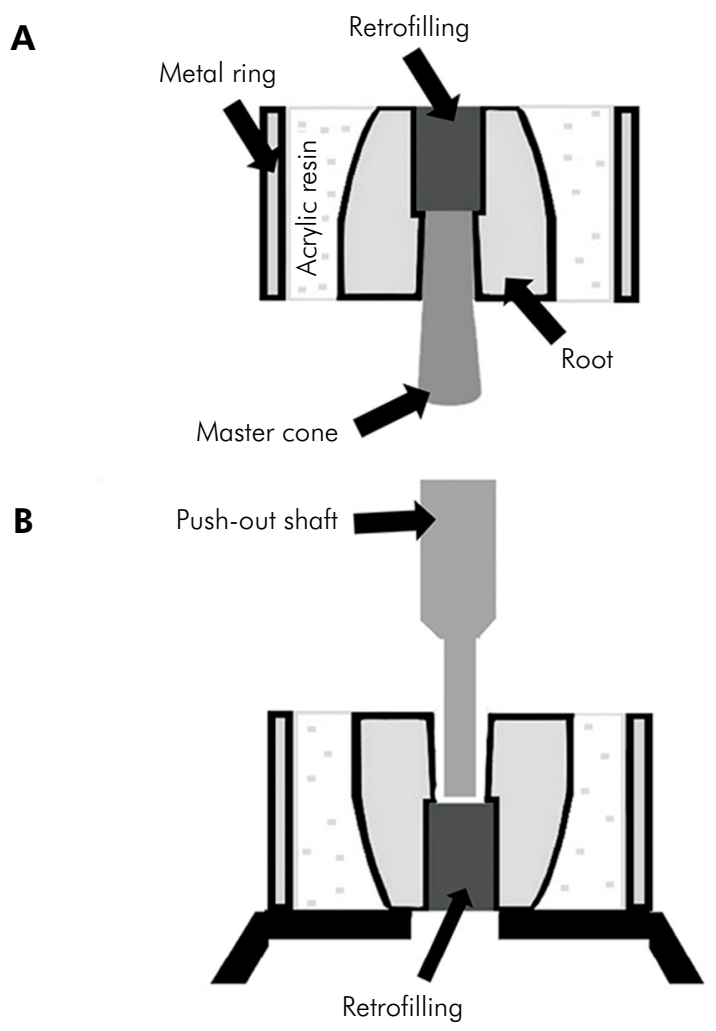

Figure. A) Root-end cavity and gutta-percha cone tug-backed at the limit between the root canal and the retrofilling. B) Simulation of the push-out test.

Following the push-out test, the specimens were examined under a stereomicroscope at $25^{\prime}$ magnification to evaluate the failure modes. Failure was considered to be adhesive if the cement was completely separated from the dentin with a dentin surface free of cement. The failure was considered cohesive if the fracture occurred within the cement, with a dentin surface completely covered by the cement. The failure was considered mixed when a dentin surface was partially covered by the cement. ${ }^{20}$

\section{Results}

The results of the push-out tests are shown in Table 1 . No statistically significant differences were identified in the bond strength of the root-end filling materials ( $p>0.001)$. MTA Angelus and ProRoot MTA exhibited mixed failures, whereas Biodentine showed both mixed and cohesive failures in the cement (Table 2). 
Table 1. Mean and standard deviation of the push-out strength values (in MPa) for the displacement of the retro-end filling materials from the specimens.

\begin{tabular}{lc}
\hline Materials & Mean (standard deviation) \\
\hline MTA Angelus & $1.82(0.47) a$ \\
ProRoot MTA & $1.29(0.32) a$ \\
Biodentine & $1.79(0.80) a$ \\
\hline
\end{tabular}

Table 2. Failure types (\%) in each tested group after the push-out test.

\begin{tabular}{lccc}
\hline Failure type & MTA Angelus & ProRoot MTA & Biodentine \\
\hline Adhesive & 10 & 10 & 0 \\
Cohesive & 30 & 30 & 50 \\
Mixed & 60 & 60 & 50 \\
\hline
\end{tabular}

\section{Discussion}

Bond strength can be defined as a process of union between two surfaces with different molecular compositions as a consequence of chemical, physical, or mechanical forces. ${ }^{21}$ Bond strength of root-end filling materials depends on the chemical composition of the cement and dentin surface. ${ }^{22}$

In the current study, the root-end cavity was prepared to evaluate the bond strength of materials under simulated clinical conditions. This method, proposed by Marques et al., ${ }^{20}$ evaluated the bond strength to dentin using a root-end cavity rather than dentin slices from various sites along the tooth root. This allowed evaluation of the behavior of the retrofilling materials throughout the extent of the retrograde cavity. The advantage of the methodology recommended by Marques et al. ${ }^{20}$ is the possibility of evaluating the behavior of the retrofilling materials confined to the retrograde cavity in the apical third, which presents density, diameter and number of dentinal tubules, different from the other thirds, in which the push out test is performed for the evaluation of endodontic sealers. Although it seems a subtle difference, this methodology allows more reliable results for the type of material tested.

Although similar bond strengths were shown for MTA Angelus, ProRoot MTA, and Biodentine therefore, the null hypothesis was accepted. However, the difference was found in structural performance of the materials (failure mode). MTA Angelus and ProRoot MTA showed mixed failure, whereas Biodentine exhibited a similar proportion of mixed and cohesive failure. Althoughall three materials tested are based on tricalcium silicate, the proportion of tricalcium silicate varies with each formulation. Both MTA formulations contain a high proportion of tricalcium silicate (MTA: $66.1 \%$ and Biodentine: 80,1\%), which is responsible for the late material hydration. ${ }^{13,14}$ MTA Angelus also contains unreacted lime (calcium oxide). The presence of this calcium oxide has been suggested to be a result of incomplete burning inside the kiln during cement manufacture. ${ }^{14}$ Therefore, the calcium ion availability from hydration varies between one MTA formulation and another, as MTA Angelus shows high levels of initial calcium release, which is a result of the reaction of calcium oxide. ${ }^{14}$ This higher calcium ion release by MTA Angelus has been reported previously. ${ }^{23}$ The ion release results in a porous and uneven surface microstructure, ${ }^{24}$ which weakens the cement structure and reduces material cohesion, and may explain the cohesive failure observed in this study.

The calcium ion leaching of Biodentine is higher because of the higher proportion of tricalcium silicate in Biodentine than that in MTA. ${ }^{14}$ Furthermore, Biodentine incorporates additives that enhance hydration, leading to better material performance. ${ }^{15,25}$ The high calcium ion release and improved material properties result in the occurrence of mixed and cohesive failures in Biodentine. $\mathrm{Ca}^{2+}$ and $\mathrm{Si}$ ions are absorbed by dentin and cause chemical and structural alterations that improve the physical properties at the bonding interface as a consequence of the increased acid resistance of dentin. ${ }^{26}$ These alterations may explain the different failure modes observed following the push-out test in the present study. Furthermore, Biodentine comprises smaller particles than other cements, which improves its interaction with dentin. It also allows better penetration within dentin tubules for mechanical retention. ${ }^{27,28}$

Although all three cements exhibited similar bond strength in the present study, the failure mode of Biodentine was different with a higher incidence of cohesive failure. This suggests that Biodentine may be used as an alternative to MTA because of its improved stability at the filling site.

\section{Conclusion}

The tricalcium silicate-based root-end filling materials tested in the present study showed similar bond strength to retrograde cavity. 


\section{References}

1. Wälivaara DA, Abrahamsson P, Isaksson S, Blomqvist JE, Sämfors KA. Prospective study of periapically infected teeth treated with periapical surgery including ultrasonic preparation and retrograde intermediate restorative material root-end fillings. J Oral Maxillofac Surg. 2007 May;65(5):931-5. https://doi.org/10.1016/i.joms.2005.12.077

2. Bernabé PF, Holland R, Morandi R, Souza V, Nery MJ, Otoboni Filho JA et al. Comparative study of MTA and other materials in retrofilling of pulpless dogs' teeth. Braz Dent J. 2005;16(2):149-55. https://doi.org/10.1590/S0103-64402005000200012

3. Torabinejad M, Smith PW, Kettering JD, Pitt Ford TR. Comparative investigation of marginal adaptation of mineral trioxide aggregate and other commonly used root-end filling materials. J Endod. 1995 Jun;21(6):295-9. https://doi.org/10.1016/S0099-2399(06)81004-6

4. Yoshimine $Y$, Ono M, Akamine A. In vitro comparison of the biocompatibility of mineral trioxide aggregate, 4META/ MMA-TBB resin, and intermediate restorative material as root-end-filling materials. J Endod. 2007 Sep;33(9):1066-9. https://doi.org/10.1016/i.joen.2007.05.006

5. Lee BN, Son HJ, Noh HJ, Koh JT, Chang HS, Hwang IN et al. Cytotoxicity of newly developed ortho MTA rootend filling materials. J Endod. 2012 Dec;38(12):1627-30. https://doi.org/10.1016/i.joen.2012.09.004

6. Chng HK, Islam I, Yap AU, Tong YW, Koh ET. Properties of a new root-end filling material. J Endod. 2005 Sep;31(9):665-8. https://doi.org/10.1097/01.don.0000157993.89164.be

7. Raskin A, Eschrich G, Dejou J, About I. In vitro microleakage of Biodentine as a dentin substitute compared to Fuji II LC in cervical lining restorations. J Adhes Dent. 2012 Dec;14(6):535-42. https://doi.org/10.3290/i.jad.a25690

8. Shokouhinejad N, Nekoofar MH, Iravani A, Kharrazifard MJ, Dummer PM. Effect of acidic environment on the push-out bond strength of mineral trioxide aggregate. J Endod. 2010 May;36(5):871-4. https://doi.org/10.1016/i.joen.2009.12.025

9. Sarkar NK, Caicedo R, Ritwik P, Moiseyeva R, Kawashima I. Physicochemical basis of the biologic properties of mineral trioxide aggregate. J Endod. 2005 Feb;31(2):97-100. https://doi.org/10.1097/01.DON.0000133155.04468.41

10. Tay FR, Pashley DH, Rueggeberg FA, Loushine RJ, Weller RN. Calcium phosphate phase transformation produced by the interaction of the portland cement component of white mineral trioxide aggregate with a phosphatecontaining fluid. J Endod. 2007 Nov;33(11):1347-51. https://doi.org/10.1016/i.joen.2007.07.008

11. Collares FM, Leitune VC, Rostirolla FV, Trommer RM, Bergmann CP, Samuel SM. Nanostructured hydroxyapatite as filler for methacrylate-based root canal sealers. Int Endod J. 2012 Jan;45(1):63-7. https://doi.org/10.1111/j.1365-2591.2011.01948.x

12. Malkondu Ö, Karapinar Kazandağ M, Kazazoğlu E. A review on biodentine, a contemporary dentine replacement and repair material. BioMed Res Int. 2014;2014:160951. https://doi.org/10.1155/2014/160951

13. Camilleri J. Characterization of hydration products of mineral trioxide aggregate. Int Endod J. 2008 May;41(5):408-17. https://doi.org/10.1111/j.1365-2591.2007.01370.x

14. Camilleri J, Sorrentino F, Damidot D. Investigation of the hydration and bioactivity of radiopacified tricalcium silicate cement, Biodentine and MTA Angelus. Dent Mater. 2013 May;29(5):580-93. https://doi.org/10.1016/i.dental.2013.03.007

15. Grech L, Mallia B, Camilleri J. Investigation of the physical properties of tricalcium silicate cement-based root-end filling materials. Dent Mater. 2013 Feb;29(2):e20-8. https://doi.org/10.1016/i.dental.2012.11.007

16. Laurent $P$, Camps J, About I. Biodentine(TM) induces TGF- $\beta 1$ release from human pulp cells and early dental pulp mineralization. Int Endod J. 2012 May;45(5):439-48. https://doi.org/10.1111/j.1365-2591.2011.01995.x

17. Saghiri MA, Garcia-Godoy F, Gutmann JL, Lotfi M, Asatourian A, Ahmadi H. Push-out bond strength of a nano-modified mineral trioxide aggregate. Dent Traumatol. 2013 Aug;29(4):323-7. https://doi.org/10.1111/i.1600-9657.2012.01176.x

18. Nagas E, Cehreli ZC, Uyanik MO, Durmaz V, Vallittu PK, Lassila LV. Bond strength of mineral trioxide aggregate to root dentin after exposure to different irrigation solutions. Dent Traumatol. 2014 Jun;30(3):246-9. https://doi.org/10.1111/edt.12070

19. Miör IA, Smith MR, Ferrari M, Mannocci F. The structure of dentine in the apical region of human teeth. Int Endod J. 2001 Jul;34(5):346-53. https://doi.org/10.1046/i.1365-2591.2001.00393.x

20. Marques JH, Silva-Sousa YT, Rached-Júnior FJ, Mazzi-Chaves JF, Miranda CE, Silva SR, et al. New methodology to evaluate bond strength of root-end filling materials. Braz Dent J. 2015 May Jun;26(3):288-91. https://doi.org/10.1590/0103-6440201300189

21. Erickson RL. Surface interactions of dentin adhesive materials. Oper Dent. 1992; Suppl 5:81-94.

22. Winik R, Araki AT, Negrão JA, Bello-Silva MS, Lage-Marques JL. Sealer penetration and marginal permeability after apicoectomy varying retrocavity preparation and retrofilling material. Braz Dent J. 2006;17(4):323-7. https://doi.org/10.1590/S0103-64402006000400011

23. Duarte MA, Demarchi AC, Yamashita JC, Kuga MC, Fraga SC. $\mathrm{pH}$ and calcium ion release of 2 root-end filling materials. Oral Surg Oral Med Oral Pathol Oral Radiol Endod. 2003 Mar;95(3):345-7. https://doi.org/10.1067/moe.2003.12

24. Borges RP, Sousa-Neto MD, Versiani MA, RachedJúnior FA, De-Deus G, Miranda CE et al. Changes in the surface of four calcium silicate-containing endodontic materials and an epoxy resin-based sealer after a solubility test. Int Endod J. 2012 May;45(5):419-28. https://doi.org/10.1111/j.1365-2591.2011.01992.x 
- Push-out bond strength of different tricalcium silicate-based filling materials to root dentin

25. Grech L, Mallia B, Camilleri J. Characterization of set Intermediate Restorative Material, Biodentine, Bioaggregate and a prototype calcium silicate cement for use as rootend filling materials. Int Endod J. 2013 Jul;46(7):632-41. https://doi.org/10.1111/iej.12039PMID:23289940

26. Han L, Okiii T. Bioactivity evaluation of three calcium silicate-based endodontic materials. Int Endod J. 2013 Sep;46(9):808-14. https://doi.org/10.1111/iej.12062
27. Atmeh AR, Chong EZ, Richard G, Festy F, Watson TF. Dentin-cement interfacial interaction: calcium silicates and polyalkenoates. J Dent Res. 2012 May;91(5):454-9. https://doi.org/10.1177/0022034512443068

28. Guneser MB, Akbulut MB, Eldeniz AU. Effect of various endodontic irrigants on the push-out bond strength of biodentine and conventional root perforation repair materials. J Endod. 2013 Mar;39(3):380-4. https://doi.org/10.1016/i.joen.2012.11.033 